\title{
Jews in the Discourses of the Polish Enlightenment
}

\author{
Richard Butterwick-Pawlikowski
}

The old-fashioned term 'genealogy' has gained in popularity among historians, as it conveys a sense of where things came from, without the teleology implied by 'origins', 'roots', or 'genesis'. From common ancestors come diverse descendants. ${ }^{1}$ The varieties of antisemitism experienced in the Polish--Lithuanian lands and encountered in Polish discourses since the later nineteenth century derive some, but by no means all, of their genetic code, as it were, from discourses about Jews in the later eighteenth century. However, the intellectual and cultural formation known as the Polish Enlightenment scattered many seeds, not all of which came to fruition, but which included the potential for philosemitism as well as antisemitism. The discourses in question are found in a range of sources, including treatises, pamphlets, correspondence, projects for legislation, and resolutions and instructions passed by the local assemblies of the Polish--Lithuanian nobility---the sejmiki. I focus in particular on the period

15 of the Four Year Sejm. The 'Polish Revolution' of 1788--92 precipitated unprecedented debate on political, fiscal, economic, social, cultural, and religious affairs in the Polish-Lithuanian Commonwealth. Many of these strands had relevance for the Commonwealth's Jews, even if Jews were only rarely the principal objects of polemical exchanges. ${ }^{2}$

The first half of the eighteenth century saw the apogee of harassment by the Roman Catholic Church of the Commonwealth's Jews, 'heretics', and 'schismatics'. ${ }^{3}$ This trajectory is only partly explained by reaction to the traumatic wars of 1648--1721, and not at all in the case of Jews, who were fellow victims rather than foes. It needs to be seen in the context of a revival 
of interest, beginning towards the end of the seventeenth century, in implementing the reforms of the Council of Trent. For example, the last diocesan synod held in the pre-partition diocese of Wilno, called by Bishop Michał Zienkowicz in 1744, passed resolutions hostile to Jews and Protestants in the context of regulations aiming at tighter discipline and higher pastoral standards among the clergy. This synod also increased the degree of episcopal control over exorcisms and the trial of suspected witches. ${ }^{4}$ This fits into a wider picture. The post-Tridentine renewal of the Church was a very long-term process across Catholic Europe. In its later stages, it shaded almost imperceptibly into what has been called 'Enlightened Reform Catholicism'. ${ }^{2}$ Politics continued to absorb most bishops, but many paid greater attention to administering their dioceses. These men were well educated. Post-Tridentine Catholicism even began to acquire an 'enlightened' sheen by the 1740s, guided by the courteous and scholarly Benedict XIV. But Pope Benedict also issued edicts against Freemasons and, at the request of the Polish episcopate, an encyclical repeating centuries-old prohibitions against

15 Christians mixing with, and serving, Jews. ${ }^{6}$

Several bishops attempted to ensure that Jewish worship and social and business contacts between Jews and Christians did not lead to the 'corruption' or even 'apostasy' of the latter, and that Jews knew their subordinate place. This was of great theological import, for it was held that the Jews, having failed to recognize the Messiah, still bore 'blind' witness to the Old Testament in their accursed exile, and that their conversion would be part of the Apocalypse. They were commanded, for example, to seek permission to repair their synagogues, to stay indoors on major Christian feasts, and to wear distinctive clothing. ${ }^{7}$

Such repressions had a more sinister impact when episcopal objectives found common ground with popular myths. In Żytomierz in 1753, the coadjutor/bishop of Kiev, Kajetan Sołtyk, initiated the trial of thirty-three Jews for alleged ritual murder. Following 
confessions obtained by torture, thirteen were sentenced to torments and death. Two abjured their religion and were spared at his request; five who only did so at the last minute were beheaded, and then solemnly buried by him in the Catholic cemetery. Sołtyk gave the affair wide publicity. His motives may have been partly pecuniary, as he was said to have threatened other Jews with similar trials in order to extort money. ${ }^{8}$ Even the learned Andrzej Załuski (whom Sołtyk would later succeed as bishop of Kraków) denounced Jews as a 'species of lizard' in a pastoral letter of 1751. They committed, he claimed, endless blasphemies, sacrileges, treacheries, deceits, thefts, seductions, and adulteries on the Catholics they inebriated, as well as murders, attested by 'public echo and a strong presumption, and still more frequent and recent examples, [of] innocent Christian children for their superstitions'. If this was the conviction of one of the most enlightened bishops of his time (who banned exorcisms without written episcopal approval, and for whom the word 'superstition' was especially pejorative), then the extent of belief in the blood libel among the clergy and laity may be imagined. ${ }^{9}$

Admittedly, economic forces often frustrated episcopal wishes to exclude Jews from positions of authority over Christians. The exhortations of Cardinal Jan Lipski failed to persuade the Kraków cathedral chapter to remove Jews from leases on the chapter's properties. ${ }^{10}$ Nevertheless, even the most powerful magnates hesitated before defying a bishop in defence of 'their' Jews. As Adam Kaźmierczyk has observed, one reason for the denser settlement of Jews in the private towns of the eastern reaches of the Commonwealth may have been the weaker influence of the Latin-rite clergy there. ${ }^{11}$

The restrictions and permissions imposed by bishops anxious to retain a proper theocratic hierarchy irked Jews. So did the bouts of trying to convert them to Christianity. Although the cause of conversion was not helped by Judaeophobic rhetoric, many among the Catholic clergy took it seriously. ${ }^{12}$ The Mariavite nuns were founded by the charismatic 
Father Szczepan Turczynowicz in the diocese of Wilno in 1737 to educate and care for converted Jewish (and Karaite and Tatar) girls, and to integrate them into Christian society. The congregation was confirmed by Bishop Zienkowicz in 1744, and noted by Benedict XIV in 1752. They soon had eighteen houses, and their own converts began to swell the ranks of the sisters. ${ }^{13}$ Some evangelists were legendary. One Dominican, Wawrzyniec Owłoczyński, who died in 1763 , was said to have convinced sixty-six Jews that Jesus of Nazareth was their true Messiah. ${ }^{14}$ The tireless Franciszek Kobielski, bishop of Łuck, ordered Jews to attend a weekly sermon by a Catholic priest, delivered in their synagogue. ${ }^{15}$

However, after about 1760, episcopal attitudes towards the Jews grew significantly 10 milder. A report written by Cardinal Lorenzo Ganganelli, the future Pope Clement XIV, condemning belief in the ritual murder of Christian children by Jews, helped to end such trials. ${ }^{16}$ In 1775 , a court of the Sejm confederacy, presided over by the bishop of Poznan and grand chancellor of the Crown, Andrzej Młodziejowski, found thirty Jews not guilty of the ritual murder of a 3-year-old girl from the Mazovian village of Grabie, because their

15 (mutually contradictory) confessions had been obtained by torture. ${ }^{17}$

Episcopal permission to build synagogues and schools became easier to obtain. Zienkowicz's successor as bishop of Wilno, Ignacy Massalski, rarely refused such requests. He would, however, generally attach caveats, such as those stating that the synagogue should not resemble a church, be located next to it, or exceed one in size. Funeral processions should 20 be discreet. He also gave permission for Jews to settle in ecclesiastical towns, where they were not already present. Michał Poniatowski, the king's brother, took a similar line in the diocese of Płock, and later in the dioceses of Kraków and Gniezno. ${ }^{18}$ In the diocese of Kujawy in 1783, the Jews of Izbica were permitted to build a synagogue provided its dimensions were appropriate to their number, that it was located thirty paces beyond the town, and that an annual quota was payable to the parish church. Moreover, the Jews were 
expected to live harmoniously and 'honestly' with the Christians of the town. ${ }^{19}$

Efforts to convert Jews to Catholicism faltered. The lack of episcopal interest gradually filtered down to the parish clergy. Massalski tried---with mixed results---to suppress the Mariavites in 1773, apparently in response to Jewish complaints, although it should also be stressed that the congregation consisted of just sixty sisters and very few material resources. ${ }^{20}$ The bishop of Wilno evidently thought conversions not worth the trouble they involved, such as furious protests from relatives. In 1787 he wrote to the parish priest of Troki:

There is very little to be gained from these neophytes, and for the most part we see in them idlers unwilling to work, and occupying themselves with roguery ... Such eagerness is the result of misunderstood zeal, which, in imprudently increasing the number of sons of the Mother Church, also increases, as experience teaches, the ranks of those unworthy of her womb. ${ }^{21}$

Conversions, usually by young and indigent persons, were a disorienting, even traumatic process, and many were unable to adjust to the excommunication imposed on them by their own communities. Fear of violent reprisals was not unknown. In 1783, Massalski ordered that all Jews (and Muslims) wishing to be baptized had to be examined on their knowledge of the

20 Catholic faith and their motivations by the parish priest or auditor, acting on express episcopal authority. Sometimes these examinations would take place in the presence of representatives of the Jewish community. Fourteen standard questions were to be asked. Following Benedict XIV, several bishops issued clear instructions forbidding the baptism of Jewish children against the wishes of their parents. ${ }^{22}$ 
Sandomierz, engaged to another Jew of the town, had been violently abducted and placed in a convent by soldiers. The suffragan bishop of Sandomierz in the diocese of Kraków, Wojciech Radoszewski, investigated the incident, and heard testimony that she had felt a vocation for a year, and wished to become a nun. At her examination by, among others, 'two respectable priests', the woman said that she felt a strong desire to accept the Catholic faith, and to live and die in it. She said this to the Jews at the convent gate and was baptized. Her engagement gifts were to be sorted out by the courts. Admittedly, the testimony cited is that of the suffragan bishop. But he did claim to have observed all the procedures in order to make sure the conversion was genuine. He does not seem to have been a zealous proselytizer. ${ }^{23}$

The diminishing scale of episcopal objectives can be gauged from their negotiations with the Sejm in 1790: in the course of a complaint against disruption of the Christian sabbath, the bishops made complaints both against taverns opening and Christians serving Jews on Sundays and holy days. But they did not raise the question of Christians serving Jews as a general point of principle. $^{24}$

Bishops had not entirely shed their prejudices. During debates on clerical taxation in 1789, the historian, poet, and bishop Adam Naruszewicz exclaimed: 'Is our clerical estate such an erroneous, arbitrary, and merely tolerated estate? So that arbitrary tributes should be thrown on us, as on Jews, in whose lewd company we have been insultingly reckoned, or on Gypsies, or on some other despicable mob?' He used the derogatory forms $\dot{z} y d y$ and cygany, rather than the correct $\dot{Z} y d z i$ and Cyganie. ${ }^{25}$ His colleague Kacper Cieciszowski, a paragon of gentleness and holiness, asked why ministers of the dominant religion were singled out for worse treatment than dissidents, 'and even the infidel Jews themselves?' ${ }^{26}$ The same point was made by a Reformed Franciscan friar, Karol Surowiecki, in a polemical exchange in print: 'We tax them almost triple; we strip them as if they were Jews, and excepting the appearances of politeness and respect, as regards civil existence, we put them almost in the 
same rank as Jews, because we decide about them without them, as sovereigns, and when it pleases us we oppress them, and extort from them. ${ }^{27}$

By the later eighteenth century, Jews were generally regarded by better-educated Christians, from the clergy and laity alike, as a socio-economic, not a religious problem. Above all, they were blamed for mass alcoholism among the enserfed peasantry. The alcohol monopoly, the propinacja, was probably the most morally and physically corrupting factor affecting the relationship between lord and peasant. Lords distilled vodka from surplus grain, and sold it to the peasants. In some years this could account for a third or a half of the revenues of magnates' latifundia. Peasants were obliged to buy---and therefore consu 10 me---fixed amounts of beer and vodka in the lords' taverns. Other items and commodities could also be obtained there, as could credit. Peasant resentments were borne by the tavernkeeper and usurer, who was traditionally a Jew. ${ }^{28}$

Clergymen also blamed the indifference of lords. For example, in 1784 the parish of Kowarsk (Kavarskas) in the diocese of Wilno contained four Catholic-run taverns (including 15 the parish priest's own) and eight Jewish ones, not to mention fifteen Jews who illegally sold alcohol 'on the side'. These points of sale, we read in the visitation records, led the 'simple folk' (prostota) to 'every kind of drunkenness, theft, Jewish superstition, and the neglect of every Divine and Church commandment'. The parish priest asked for the bishop's advice on how to prevent such opportunities, 'because the lords do not listen to the Word of God,

20 although they know the damage to their own interests'. ${ }^{29}$ We may also note residual fears of the Judaization of the (not so) faithful.

If we are to believe the bishop of Livonia, Józef Kazimierz Kossakowski, some clergymen were their own worst enemies in this regard. Among the anti-heroes of his novel Xiadz pleban ('The Parish Priest') we find a choleric preacher of fire and brimstone, who publicly thrashed his parishioners for 'drinking with foreign Jews . . the enemies of Christ, 
wizards and blasphemers, despite the parish priest's own tavern, in which the drinks, although dearer, in smaller measures, and not so good, were at least free of all suspicion' ${ }^{30}$ In this case the residual Judaeophobia is among the objects of satire.

Be that as it may, growing criticism of Jewish tavern-keepers for inebriating the peasantry did seem to have had an effect, especially in the areas touched by the Koliyivshchyna: it appears that more than half of the taverns and inns in Polish Ukraine were transferred from Jewish to Christian leaseholders between 1778 and $1784 .{ }^{31}$ The rebellion scare of $1789^{32}$ spurred further calls to deprive Jews of taverns and inns.

Discussions of the condition of the Commonwealth's Jews were especially abundant during the Four Year Sejm, or the Polish Revolution, of 1788--92. When many burning political and social questions were discussed, it was not surprising that enlightened minds turned also to what appeared to be the disordered and anomalous state of Jewish affairs. I shall focus first on three prominent political thinkers. ${ }^{33}$

At the time, the most important of this trio was Hugo Kołłątaj, a politically ambitious clergyman with an unorthodox personal theology which leaned towards deism, although it acknowledged an active Divine Providence. The subject of Jews was given a separate chapter in his Prawo polityczne narodu polskiego ('Political Law of the Polish Nation'), published at the end of 1789 , reflecting their status as a social as well as a religious group. It was a separateness which Kołłątaj wished to end as soon as possible. Although toleration for all non-Christians had been assured, he wrote, the Jews were too numerous, and were like a privileged estate, insufficiently subject to governmental authority. They should therefore be ordered to shave their beards and dress as Christians did. Jewish courts would be reduced and subjected to supervision by local government, and in cases of appeal would be subordinated to the central ecclesiastical commission he wished to establish. Kołłątaj particularly wanted to eradicate rabbinical excommunications. All official documents and court proceedings were 
to be in Polish, and nobody could become a rabbi or other minister of religion without a certificate of proficiency in Polish and Latin from the Educational Commission. Four years would be allowed to implement the law. All kahals would be abolished, and local government would supervise a modest tax to maintain Jewish ministers, until the kahals' debts were paid off. No further debts would be permitted. Jews would be banned from brewing, distilling, and selling alcohol, within a year of the law's passage. Other trades and occupations would be open to them, subject to the towns’ privileges, and Kołłątaj did not wish them to be coerced into any particular occupation. However, within a year, no vagrancy would be tolerated, and alms could only be given to the old and infirm. This far-reaching programme of assimilation for the hundreds of thousands of the Commonwealth's Jews was certainly ambitious. $^{34}$

Comments on Jews by Stanisław Staszic, a burgher who had unwillingly taken lower orders to please his mother, exceeded Kołłątaj's in their hostility. In his Przestrogi dla Polski ('Warnings for Poland') of 1790, he compared Jews to a plague of locusts---economically and morally disastrous for burghers and peasants alike. But the measures he proposed were similar: a ban on their selling alcohol, their subjection to the urban authorities, and the supervision of their schools by the Commission for National Education. He was under the mistaken impression that Jews conducted religious rites not in Hebrew, which he thought they had forgotten, but in 'corrupted German'. They should learn Polish forthwith. ${ }^{35}$

$$
\text { Józef Pawlikowski, a layman whose ancestors had gone from being nobles to }
$$
burghers, was more sensitive to Jewish cultural and religious distinctiveness, and was well aware of the poverty in which most Jews lived. He wanted their 'civilizing' (ucywilizowanie), but he refused to countenance coercive methods. The one breach he was prepared to make in their 'natural liberty' was a temporary bar on them leasing taverns, in order to break their economic dependence on inebriating the peasantry. But they would equally temporarily be 
freed from recruitment into the army. Otherwise, he looked to reformed schooling in the Polish language to make Jews into 'Poles'---without interfering in their 'religion', in which he comprehended not only theology, worship, and prayer, but also sumptuary and dietary requirements. The tone was that of a passionate but well-informed and practical campaigner against injustice. Peasant, burgher, Jew, and clergyman: all were vulnerable to the licence of the nobility. ${ }^{36}$

Pawlikowski's tone was unusual among Christian burghers. The anonymous author of Starych uprzedzeń nowe roztrząśnienie, do reformy rząu kraiowego służącego ('A New Discussion of Old Prejudices, Serving the Reform of the Country'), published at the beginning of 1790, denounced the prejudices of the szlachta---'absolute lords' and 'despots' over the enslaved peasants, 'the most useful part of the people'. But in denouncing some prejudices, he revealed others, especially towards 'loathsome Jewry, banished from other states ... these people, devious by nature, and hateful to Christianity'. Burghers, he claimed, were driven to desperation and driven out of towns by usurious Jews selling drink. He warned that neophytes had often converted for material advantage, exploited true Christians like Jews, and sent money abroad to their patriarch, Jakub Frank. ${ }^{37}$

Frank also featured in an exchange between two or three pamphleteers in April--May 1790. The first two pamphlets accused neophytes of using Catholicism to mask undesirable economic activities, while remaining Frankist sectaries at heart. By sending their 'patriarch' money, they damaged the economy further. ${ }^{38}$ The author of the second pamphlet, Dwór Franka ('The Court of Frank'), who himself claimed to be a neophyte (of his own free will), having prefaced his remark with 'although I am and always shall be for toleration', declared that he would if necessary establish a 'Spanish Holy Inquisition', with 'investigators and spies' to ask neighbours about the neophytes' activities. He also recalled, approvingly, the burning of the nobleman Kazimierz Łyszczyński for atheism in $1689 .{ }^{39}$ A riposte accused 
him of coveting the fortunes of others, defended the honesty of neophyte traders, and claimed that the knowledge of human souls should be left to God. ${ }^{40}$

Although the warnings that Frankist neophytes continued to behave like Jews might seem to anticipate late nineteenth-century antisemitic discourses, in most respects this exchange only reinforces the point that during the Four Year Sejm the Jewish question was overwhelmingly regarded not as a religious but as a social, economic, and cultural problem, with political and fiscal ramifications. ${ }^{41}$ It should be added, however, that many of the topics which to noble supporters of reform appeared to be empty rituals, or even superstitions, were, even for the small number of maskilim, an integral part of the Jewish religion. ${ }^{42}$

The impetus for reform of the Jews at the Four Year Sejm owed much to tensions between nobles and Christian burghers. From the very beginning of the Sejm, Jewish and burgher lobbying had taken place in an atmosphere of mutual rivalry and hostility, aggravated by those members of the Sejm who were ill disposed to the burghers. A group of Jewish merchants which, as Jakub Goldberg has shown, later developed into an organized group of 15 plenipotentiaries asked for permission for three hundred Jewish traders to reside permanently in Warsaw, and for the right to unrestrained economic activity in royal and ecclesiastical towns, offering substantial contributions in return. ${ }^{43}$ The Christian population of Warsaw for its part was becoming increasingly angered by the extended suspension (for the duration of the Sejm) of the city's privilege de non tolerandis Judaeis. Many Jews settled in the city and took up employment in such areas as crafts, trade, and brewing. Among them were also diverse criminals, especially traders in stolen goods, who benefited from the plague of pickpockets (most of whom were Christians). ${ }^{44}$

Feeling the competition, Christian traders and craftsmen put pressure on the corporation for their expulsion, threatening violence. Michał Jerzy Mniszech, the grand marshal of the Crown, promised to do this in March 1790, although it was another month 
before the Jews were moved out. By mid-May, however, the city again contained many Jewish traders, and tensions rose. The spark came on 16 May, when a Christian tailor clashed with a Jew carrying cloth, and a (false) rumour spread that the Jews had killed the tailor. The mob, composed mainly of apprentices and their masters, attacked the Jews and their property, and stoned the marshal's guard, before finally being pacified by additional troops. Many nobles were outraged, seeing the attack on the Jews as a threat to themselves. Although the (non-fatal) tumult offended enlightened sensibilities, most nobles treated Jews as a convenience. The following day in the Sejm, several speakers demanded exemplary punishment not just of those guilty of assault, but of the Warsaw burghers as a whole. For a while, the Jewish question now received more attention than the urban one. ${ }^{45}$

Mateusz Butrymowicz, the envoy from Pińsk, the predominantly Jewish town at the gentle confluence of the rivers Prypyats and Pina, reminded the Sejm of a project he had submitted the previous November. In many respects, his would have been a highly enlightened reform, granting full freedom of worship, forbidding the conversion of Jews to

15 Christianity by coercion or trickery ('namową podstępną'), and equalizing the economic status and civic rights of Jews and Christians within royal towns. It was also typical of the Enlightenment in that it expected Jews to lose all external signs of cultural distinctiveness ('wishing to adapt Jewry living in the territories of the Commonwealth to the laws of the country and national customs'). Polish was to be used in all transactions, and only strictly 20 religious books would be permitted in 'Jewish', which probably referred to both Hebrew and Yiddish. Likewise, the kahals would lose all powers except in purely religious matters. Jews were to be removed from taverns and distilleries, and were expected to take up useful trades and agriculture. ${ }^{46}$

This package generally satisfied the postulates of a small number of reform-minded Jews, and a section of the nobility. Essentially, it was in the same assimilationist spirit as 
Kołłątaj’s prescriptions and the partial emancipation imposed by Joseph II in the Habsburg territories. ${ }^{47}$ However, as Krystyna Zienkowska has argued, such a reform would have practically eliminated any chance of the admission of the burghers to political rights. Both its author, for all his sincere convictions in favour of toleration, and some of its supporters probably intended it to have just such an effect. ${ }^{48}$

In the Sejm on 19 June 1790, Jacek Jezierski, castellan of Łuków and the prime example of an enterprising noble in economic competition with burghers, called for the establishment of a deputation to reform the Jews, which would take Butrymowicz's project as its starting point. He hailed Butrymowicz as 'a friend of the human race, of whatever

10 religion', and reminded the Sejm that the Jews, unlike the towns, did not threaten rebellion, but humbly asked for their affairs to be put in order. The Sejm appointed a deputation, including Jezierski and Butrymowicz. ${ }^{49}$

By 16 August, the deputation's project was ready. It largely followed Butrymowicz's concepts, with the first article guaranteeing religious toleration for all, except apostates from 15 Catholicism, and even providing that all public acts should refer to 'the people of the Old Covenant' (lud starozakonny) rather than 'infidels' (niewierni). The title of rabbi (rabin) would be replaced by that of 'teacher' (nauczyciel), who was to play a similar role in enlightening his congregation as the Catholic pleban. The anti-clericalism manifest towards Christian clergy was also apparent in the various provisions to prevent rabbinical extortions.

20 In order to have an 'industrious and polite' and 'informed and enlightened' Jewish population, the Educational Commission was to bring forward means by which 'the youth of the Jewish people and the teachers who are to teach that youth could improve themselves in all that is useful and necessary to civil life', within two months. The organs of local government, Civil-Military Commissions, would ensure that Jews used 'the language of the country', although a degree of Hebrew and Polish bilingualism would be acceptable in 
official documents. ${ }^{50}$

However, the Sejm did not find time to consider the deputation's project, and the question slipped down the political agenda. Attempts to present it were opposed by some members of the deputation (from the province of Małopolska) on 16 August 1790 and on 24 May 1791. A rival project was presented by one of those members and read out on the latter date, but it was not discussed either. ${ }^{51}$ I would again stress the low level of interest aroused by what was considered to be the purely religious element of the Jewish question. We should also note that the postulate of subjecting Jews to municipal authority was unwelcome to the Jews themselves. ${ }^{52}$

At least eleven local assemblies of the nobility, or sejmiki, held in November 1790, favoured some kind of reform of the Commonwealth's Jews. ${ }^{53}$ None of these instructions, however, shared the relatively humanitarian tone of Butrymowicz's project. The Wilno sejmik simply highlighted 'the need for a new law to reform completely their estate and condition', and most other Lithuanian instructions were also laconic. The exception was that of Wołkowysk, which pronounced the 'Jewish nation' to be the 'most damaging part of our state ... a people engaged in fraud and living off the work of industrious peasants ... the evident cause of the impoverishment of the country'. It called for Jews to be excluded from the production and sale of alcohol, and to be forced to work in agriculture and craft.

In Mazovia, the Wyszogród instruction recommended an improved version of

20 Butrymowicz's project because 'the most particular aim of every state is that no part of the inhabitants should remain in inactivity, useless to the country, and moreover harmful to the fortunes of citizens'.** The Czersk sejmik wanted to reduce Jewish autonomy and alterity. Jewish children were to be taught the Polish alphabet, for use in contracts, while kahals would record religious decisions in Polish, and rabbis would no longer have powers to judge civil cases between Jews. Kahals would also lose all powers of taxation. 
It is striking that demands for Jewish reform came only from Lithuania and Mazovia (although even there, only from a minority of sejmiki). Despite their numbers, Jews evidently were not felt to be a pressing problem in the south-east of the Commonwealth. Perhaps the shared trauma of the 1768 massacre and a shared prosperity since then had led to less antipathy towards the Jews there. Or perhaps the key was in the economic interdependence of Jews and magnates in the region. The Volhynian sejmik demanded that, on private estates at least, Jews continue to be able to trade in alcohol. ${ }^{54}$

The Law on Royal Towns, passed on 18 April 1791 and incorporated into the Constitution of 3 May 1791, opened urban citizenship to Christians of all denominations. We have already seen how intense was the rivalry between Christian and Jewish inhabitants in many towns. Many nobles employed Jews, but they could never imagine them as equals. The exclusion---for the moment at least---of Jews from urban citizenship was also motivated by the conviction that they were a separate and largely unassimilated 'nation' that required coherent and separate legislation. Moreover, given that the overwhelming majority of Jews 15 lived in private towns, it would have caused great complications to treat Jews equally with Christians in royal towns, effectively cutting them off in legal terms from most other Jews. ${ }^{55}$ Nevertheless, Reverend Surowiecki worried that 'newly educated youngsters, who think in the French way ... even whisper in Warsaw about priests' wives and citizenship for Jews. And what else is needed? Are these not French steps?'56

The Sejm never got around to considering the projects for Jewish reform. But the Police Commission of the Two Nations, established after the Constitution of 3 May, did deem that the medieval noble privilege of no incarceration without trial, neminem captivabimus nisi iure victum, applied to urban Jews on the same basis as it applied to Christian burghers---who had received it by the Law on Royal Towns. In this way, one of the defining features of Polish citizenship was extended to some Jews. Jews in royal towns, now renamed 'free 
towns', generally benefited from being put under the authority and protection of the Police Commission, rescuing them from the newly autonomous municipal corporations. Some of the commission's interventions protected Jews from disproportionate burdens of taxation and quartering. But the leaders of kahals were not always pleased; ordinary Jews began to appeal against oppressive practices, and the commission responded by forbidding excommunications. ${ }^{57}$

The tone among the social élite in the spring of 1792 was expressed by the presence of the king and other leading Catholics at the wedding party of the daughter of the Jewish financier Szmul Zbytkower. Foreign Jews appeared in 'French' costume---a breach with tradition. The dances were held in the king's own gardens at Łazienki. A newsletter recorded: 'The Jews and others are inexpressibly content that the king was there in his own person for the breaking down of prejudices. ${ }^{58}$

The monarch was an interested party. On the eve of the first anniversary of the Constitution of 3 May, having received death threats and fearing his assassination during the

15 festivities, he wrote a testament to the marshal of the Sejm, in which he asked for his debts to be paid. This, he explained, could be done by the Jews in return for 'such internal arrangements in their nation, which cannot harm the Polish nation' ${ }^{59}$ Let us note that however Stanisław August may have understood the 'Polish nation', he considered the Jews to be a separate 'nation'.

It was in expectation of such arrangements that Jews participated in the celebrations of 3 May 1792---separately from Christians, it should be added, in services at synagogues. The Gazeta Narodowa i Obca published the Polish translation of a hymn 'sung by Jews in Warsaw and other towns of the Commonwealth by all communities of the Jewish nation' in the synagogues and 'offered', presumably to the king and Sejm, by the Jewish delegates in the capital. Although according to Artur Eisenbach the language (in the original Hebrew) is 
essentially Pentateuchal, some of the lines, when translated from Polish into English, are also reminiscent of Alexander Pope's epitaph for Isaac Newton:

God, the father of all people, shall crown this work.

He said: let there be light, and there was light.

He said again: let there be light; Stanisław came forth, who by enlightenment saved the nation from death. ${ }^{60}$

The lines also made a humanitarian plea. Although such hopes were undoubtedly limited to a small, metropolitan, prosperous, and well-educated circle, the striking Enlightenment rhetoric of the hymn shows that the Haskalah cannot be ignored altogether in discussions of Jews in the late eighteenth-century Commonwealth.

However, despite such optimism, and the king's hopes that grateful Jews would pay off most of his debts, it proved impossible for supporters of a general reform of the Jews to 15 initiate a debate on the measure in the Sejm. Even if such a reform had been passed, it would probably have contained fewer rights for Jews, and more interference from the state and municipal authorities, than the deputation's final project, which was agreed to by a majority of its members on 20 May 1792, and presented to the Sejm by its chairman, Hugo Kołłątaj, on 29 May. As this was the last day of the Sejm's deliberations, before it was adjourned in 20 the early hours of the following morning, the project was lost in the mass of other business and was not discussed. ${ }^{61}$

This final project, largely as a result of the resistance mounted by the plenipotentiaries of the burghers, would have given the Jews less self-government than earlier versions. On the other hand, largely as a result of lobbying by Jews, the assimilationism so evident in Butrymowicz's project and the deputation's project of 1790 was toned down. Jews were to be 
given more time to abandon their traditional dress, beards were to be permitted, and more understanding was shown towards the observance of dietary laws and the sabbath. Similarly, rather less emphasis was put on using the Polish language in business and in schools. ${ }^{62}$

In contrast, a general reform of the Orthodox Church in the Commonwealth, granting it an autonomous or 'autocephalous' hierarchy, was passed in the last days of the Sejm. This occurred, however, only as a result of the evident and urgent need, in the face of the Russian invasion, to curtail the control hitherto exercised over the Commonwealth's Orthodox communities by the Holy Synod in St Petersburg. A comparable geopolitical imperative was lacking in the case of Polish--Lithuanian Jews. ${ }^{63}$

In the laws and projects of the Four Year Sejm, all non-Catholic confessions, Christian and Jewish alike, were expected to conduct their non-liturgical affairs at least partially in the Polish language. There was no trace of modern ethnic nationalism here, but nor was there in the misguided efforts of Joseph II to impose German on his territories. In addition, according to the relevant paragraphs of the Project for the Form of Government, which, again, the Sejm did not manage to consider, other churches and religions were to submit their schools to the Commission for National Education. Without touching articles of faith and rites, the commission's visitors would ensure that the same instruction was given as in other schools, 'so that the tolerated difference of opinion should in no way spoil the uniformity of civic spirit, and attachment to the constitution'. To this end the commission was to draw up a 'constitutional catechism', which was to be taught in all schools. These provisions were repeated in the project for the Educational Commission, which---like the Jewish reform---the Sejm did not in the end find time to consider. In essence, members of all creeds would worship freely in their own way, but a common civic morality was to be taught by all religions. ${ }^{64}$ 
'Polish' nation out of Ruthenians and Jews, Lithuanians and Germans, using the Polish language, and preaching the same civic and moral virtues regardless of confession. Most discourse referred to a 'Jewish nation'. But Kołłątaj exemplified a trend. Traditional hatred of Jews, founded in religion, undoubtedly abated among the enlightened elite. At the same time, however, economic and social rivalries between Jews and Christian burghers were worsening, and some nobles were prepared to exploit the Jewish question in their own rivalry with the burghers. Most enlightened minds---even the relatively realistic and humane Pawlikowski---believed the solution lay in pushing Jews out of their 'substantially Jewish universe $^{95}$ and giving them similar burdens and rights as Christian inhabitants of towns. With minds concentrated by a rebellion scare in the Ukraine, they also wished to defuse tension in the countryside by moving Jews out of the production and sale of alcohol.

15 With all the caveats mentioned at the start of this article, where in enlightened discourses might we locate the genealogy of subsequent attitudes to Jews in Poland? On the one hand, Enlightenment discourses recoiled from persecution of religious minorities, and emphasized the common humanity of all inhabitants of the Commonwealth. On the other hand, the enlightened expectation that compelling Jews to assimilate into Christian society would solve 20 rising economic and social tensions, for which the Jews were blamed, often in abusive language, both underestimated Jewish reluctance to abandon much of those things which made them distinctively Jewish (which grew under the influence of hasidism), and the intractability of rural and urban social problems. Moreover, unsympathetic foreign regimes imposed their own solutions in the nineteenth century. Perhaps the concept of a Pole of the Mosaic faith, implicit in some (but not all) Enlightenment discourses, was an impossible 
dream for more than a minority of Jews, and was unacceptable to most Christian peasants or petty-bourgeois. The disappointment of that dream after the crushing of the 1863 uprising would encourage racist and ethnic nationalist antisemites.

Earlier versions of this article were presented to the seminar run by Professor Susanne Marten-Finnis at the University of Portsmouth in 2008 and the annual conference of the Institute for Polish--Jewish Studies at the Polish Embassy in London in 2009. It draws on my monograph Polska rewolucja a Kościót katolicki, 1788--1792 (Kraków, 2012), of which a shorter and more tightly focused version has been published as The Polish Revolution and the Catholic Church, 1788--1792: A Political History (Oxford, 2012). I am particularly grateful to Professor Antony Polonsky for his comments and encouragement, as well as for allowing me to read the first six chapters of his The Jews in Poland and Russia, i: 1350--1881 (Oxford, 2010) before its publication.

${ }^{1}$ A prominent example of this usage is G. D. Hundert, Jews in Poland--Lithuania in the Eighteenth Century: A Genealogy of Modernity (Berkeley and Los Angeles, 2004).

${ }^{2}$ See especially J. Lukowski, Disorderly Liberty: The Political Culture of the Polish--Lithuanian Commonwealth in the Eighteenth Century (London, 2010), chs. 9--11.

${ }^{3}$ See, among others, M. Teter, Jews and Heretics in Catholic Poland: A Beleaguered Church in the Post-Reformation Era (Cambridge, 2006); W. Kriegseisen, Ewangelicy polscy i litewscy w epoce saskiej (1696--1763): Sytuacja prawna, organizacja i stosunki międzywyznaniowe (Warsaw, 1996); id., 'Between Intolerance and Persecution: Polish and Lithuanian Protestants in the 18th Century', Acta Poloniae Historica, 73 (1996), 13--27; B. Skinner, The Western Front of the Eastern Church: Uniate and Orthodox Conflict in Eighteenth-Century Poland, Ukraine, Belarus, and Russia (DeKalb, Ill., 2009).

${ }^{4}$ J. Kurczewski, Biskupstwo wileńskie od jego zatożenia aż do dni obecnych, zawierające dzieje $i$ prace biskupów i duchowieństwa djecezji wileńskiej, oraz wykaz kościołów, klasztorów, szkół i zakładów dobroczynnych i społecznych (Vilna, 1912), 137--40. 
Published in Polin: Studies in Polish Jewry, vol. 27, 2015, pp. 45-62

${ }^{5}$ See, among others, N. Aston, Christianity and Revolutionary Europe, c.1750--1830 (Cambridge, 2002), 14--15, 41, 57--61, 77--82, 111--12; O. Chadwick, The Popes and European Revolution (Oxford, 1981), 193, 198--203, 391--5; P. Hersche, 'Der österreichische Spätjansenismus: Neue Thesen und Fragestellungen', in E. Kovács (ed.), Katholische Aufklärung und Josephinismus (Vienna, 1979), 180--96.

${ }^{6}$ See J. Dygdała, 'Episkopat rzymsko-katolicki doby saskiej: Aktywność w życiu publicznym Rzeczypospolitej', in A. Sucheni-Grabowska and M. Żaryn (eds.), Między monarcha a demokracja: Studia z dziejów Polski XV--XVIII wieku (Warsaw, 1994), 332--76; id., 'U początków katolickiego oświecenia w Polsce? Z działalności kościelnej biskupów Andrzeja Stanisława Załuskiego i Adama Stanisława Grabowskiego', in K. Stasiewicz and S. Achremczyk (eds.), Między barokiem a oświeceniem: Nowe spojrzenie na czasy saskie (Olsztyn, 1996), 181--7; Chadwick, Popes and European Revolution, 17, 30, 32, 111, 138, 166, 173--4, 184, 238, 295--8, 316, 398--401, 557; M. Rosa, 'The Catholic Aufklärung in Italy', in U. L. Lehner and M. Printy (eds.), A Companion to the Catholic Enlightenment in Europe (Leiden, 2010), 224--9. Benedict XIV's encyclical A Quo Primum (1751) is discussed by Teter, Jews and Heretics in Catholic Poland, 89--90.

${ }^{7}$ Teter, Jews and Heretics in Catholic Poland, passim; Hundert, Jews in Poland--Lithuania, ch. 3; A. Kaźmierczyk, ‘Polscy biskupi wobec Żydów w XVIII wieku', in A. Kaźmierczyk et al. (eds.), Rzeczpospolita wielu wyznań (Kraków, 2004), 349--56.

${ }^{8}$ M. Czeppe, 'Sołtyk, Kajetan Ignacy', in Polski stownik biograficzny, xl (Kraków and Warsaw, 20 2001), 387, 390. Cf. K. Rudnicki, Biskup Kajetan Sottyk, 1715--1788 (Kraków and Warsaw, 1906), $15--18$.

${ }^{9}$ Quoted after Kaźmierczyk, 'Polscy biskupi wobec Żydów', 355. Cf. B. Kumor, Dzieje diecezji krakowskiej, iv (Kraków, 2002), 622. See Z. Guldon and J. Wijaczka, 'The Accusation of Ritual Murder in Poland, 1500--1800', Polin, 10 (1997), 99--140.

${ }^{10}$ Teter, Jews and Heretics in Catholic Poland, 85.

${ }^{11}$ A. Kaźmierczyk, Żydzi $w$ dobrach prywatnych $w$ świetle sadowniczej i administracyjnej praktyki dóbr magnackich w wiekach XVI--XVIII (Kraków, 2002), 170--5.

${ }^{12}$ See J. Goldberg, ‘Żydowscy konwertyci w społeczeństwie staropolskim', in A. Izydorczyk and 
A. Wyczański (eds.), Społeczeństwo staropolskie: Studia i szkice, iv (Warsaw, 1986), 195--214, 226;

M. Teter, 'Jewish Conversions to Catholicism in the Polish--Lithuanian Commonwealth of the Seventeenth and Eighteenth Centuries', Jewish History, $17 / 3$ (2003), 257--83.

${ }^{13}$ M. Borkowska, 'Dzieje zgromadzenia Mariae Vitae czyli mariawitek', Nasza Przeszłość, 93 (2000), 107--52; ead., Zakony żeńskie w Polsce w epoce nowożytnej (Lublin, 2010), 118, 218--21, $348--55$.

${ }^{14}$ K. Górski, Zarys dziejów duchowości w Polsce (Kraków, 1986), 260. If this was considered notably high, conversions were hard to come by. According to statistics from 1718--55 (cited by Teter, 'Jewish Conversions to Catholicism', 259--61), the number of Jews converted by the Jesuits (usually 20--30 a year) was significantly less than than the number of Lutherans and Orthodox, although more than the number of Calvinists---who were much less numerous than Jews in the eighteenth-century Commonwealth.

${ }^{15}$ On Kobielski’s activities, see G. D. Hundert, 'Identity Formation in the Polish--Lithuanian Commonwealth', in K. Friedrich and B. M. Pendzich (eds.), Citizenship and Identity in a Multinational Commonwealth: Poland--Lithuania in Context, 1550--1772 (Leiden, 2009), 131--47.

${ }^{16}$ Guldon and Wijaczka, 'Accusation of Ritual Murder'.

${ }^{17} \mathrm{~S}$. Waltoś, 'L'Abolition de la torture et des procès contre les sorcières en Pologne', Archiwum Iuridicum Cracoviense, 11 (1978), 109--11.

${ }^{18}$ T. Kasabuła, Ignacy Massalski, biskup wileński (Lublin, 1998), 477--84; M. Grzybowski,

20 'Kościelna działalność Michała Jerzego Poniatowskiego biskupa płockiego', Studia z Historii Kościoła w Polsce, 7 (1983), 46, 154.

${ }^{19}$ J. Wysocki, Józef Ignacy Rybiński, biskup włocławski i pomorski, 1777--1806: Zarys biograficzny na tle rządów diecezją (Rome, 1967), 230--1.

${ }^{20}$ Goldberg, ‘Żydowscy konwertyci w społeczeństwie staropolskim’, 212--13. Seven of the eight houses located beyond the pre-partition boundary of the Commonwealth survived, as well as four of those remaining in Poland--Lithuania, following a dramatic journey to Rome by the order's visitor. The Holy See refused to recognize the suppression. In 1788, Massalski finally gave permission to the congregration to renew its activity within his diocese (with a greater emphasis on work in hospitals). 
Borkowska, 'Dzieje zgromadzenia Mariae Vitae', 124--33; ead., Zakony żeńskie, 348--55.

${ }^{21}$ Quoted after Kasabuła, Ignacy Massalski, 484.

${ }^{22}$ Ibid. 484--91. See, in general, Goldberg, ‘Żydowscy konwertyci w społeczeństwie staropolskim', 218--29.

${ }^{23}$ Wojciech Radoszewski to Ignacy Potocki, Sandomierz, 6 Dec. 1791: Archiwum Główne Akt Dawnych, Warsaw (hereafter AGAD), Archiwum Publiczne Potockich, 279b, vol. vi, 459--60.

24 ‘Przełożenia Collegii Episcoporum Prześwietney Deputacyi, do traktowania z niemi w Interessach Duchownych wyznaczoney podane’: Archiwum Archidiecezji Gnieźnieńskiej, Gniezno, Archivum Capituli, B84, fos. 92--3.

${ }^{25}$ Gtos Adama Naruszewicza, biskupa smoleńskiego, za duchowieństwem na sessyi seymowey roku 1789 dnia 16 marca (n.p., n.d.).

${ }^{26}$ Mowa jaśnie wielmożnego jmci Xiędza Cieciszowskiego, biskupa kijowskiego, miana na sessyi seymowey dnia 16 marca r. 1789 (n.p., n.d.).

${ }^{27}$ [Karol Surowiecki], Gandżara prawdy niecnotliwego cygana chłoszczaca, czyli na paszkwil pod tytułem cygan cnotliwy gandżara prawdy nie chloszczacy odpowiedź, dedykowana temuż cyganowi przez autora U.N.P.P.S. (Warsaw, 1792), 76--7.

${ }^{28}$ See J. Lukowski, Liberty's Folly: The Polish--Lithuanian Commonwealth in the Eighteenth Century, 1697--1795 (London, 1991)

${ }^{29}$ Ukmergès dekanato vizitacija 1784 m., ed. S. Jegelevičius (Vilnius, 2009), 42.

${ }^{30}$ [Józef Kazimierz Kossakowski], Xiądz pleban (Warsaw, 1786), 33.

${ }^{31}$ D. Stone, The Polish--Lithuanian State, 1386--1795 (Seattle, 2001), 304.

${ }^{32}$ On this panic, see R. Butterwick, 'Deconfessionalization? The Policy of the Polish Revolution towards Ruthenia, 1788--1792', Central Europe, 6/2 (2008), 91-121.

${ }^{33}$ They are discussed by, amongst others, A. Eisenbach, Emancypacja Żydów na ziemiach polskich 1785--1870 na tle europejskim (Warsaw, 1988), 82--4, 88--9, 106--10; Polonsky, Jews in Poland and Russia, i. 200--2.

${ }^{34}$ H. Kołłątaj, Listy Anonima i Prawo polityczne narodu polskiego, ed. B. Leśnodorski and H. Wereszycka, 2 vols. (Warsaw, 1954), ii. 328--33. 
${ }^{35}$ S. Staszic, Przestrogi dla Polski, in id., Pisma filozoficzne i społeczne, ed. B. Suchodolski, 2 vols. (Warsaw, 1954), i. 298--303.

${ }^{36}$ [Józef Pawlikowski], Myśli polityczne dla Polski (Warsaw, 1789), 106--27. See E. Rostworowski, “"Myśli polityczne” Józefa Pawlikowskiego’, in id., Legendy i fakty XVIII wieku (Warsaw, 1963), 195--264. Cf. J. Goldberg, ‘Żydzi polscy XVIII wieku w pracach Jerzego Michalskiego i Emanuela Rostworowskiego', in Z. Zielińska and W. Kriegseisen (eds.), W kręgu badaczy dziejów politycznych XVIII wieku: Józef Feldman, Emanuel Rostworowski, Jerzy Michalski (Warsaw, 2010), 164.

${ }^{37}$ Starych uprzedzeń nowe roztrzaśnienie, do reformy rzadu kraiowego stużacego (Warsaw, 1790), 34--5.

${ }^{38}$ List przyjaciela Polaka, niegdyś w Warszawie, a teraz w Wrocławiu mieszkającego, do obywatela warszawskiego, wyjawiający sekreta neofitów, poprawy rządu wyciagajace, pisany dnia 2 miesiąa kwietnia roku 1790, in Materiaty do dziejów Sejmu Czteroletniego (hereafter MDSC), vi, ed. A. Eisenbach et al. (Wrocław, 1969), 175.

${ }^{39}$ Dwór Franka, czyli polityka nowochrzeńców odkryta przez neofite jednego dla poprawy rządu roku 1790, in MDSC, vi. 181--2.

${ }^{40}$ Odpowiedź zazdrosnemu cudzego dobra i szukającemu stawy dla siebie z pokrzywdzenia honoru bliźniego przez wydane o neofitach i dworze Franka pisma (1790), in MDSC, vi. 182--7.

${ }^{41}$ I draw this conclusion both from the documents collected in MDSC, vol. vi, and from the 20 historiography.

${ }^{42}$ M. Wodziński, “'Civil Christians”: Debates on the Reform of the Jews in Poland, 1789--1830’, in B. Nathans and G. Safran (eds.), Culture Front: Representing Jews in Eastern Europe (Philadelphia, 2008), 48--53, 66--8.

${ }^{43}$ J. Goldberg, 'Pierwszy ruch polityczny wśród Żydów polskich: Plenipotenci żydowscy w dobie Sejmu Czteroletniego', in J. Michalski (ed.), Lud żydowski w narodzie polskim (Warsaw, 1994), 45-63.

${ }^{44}$ M. Majewski, 'Przestępczość żydowska w Warszawie doby Sejmu Wielkiego', Kwartalnik Historii Żydów, 234 (2010), 143--56. 
${ }^{45}$ See Eisenbach, Emancypacja Żydów na ziemiach polskich, 70--113; Polonsky, Jews in Poland and Russia, i. 210--14; K. Zienkowska, “"The Jews Have Killed a Tailor”: The Socio-Political Background of a Pogrom in Warsaw in 1790', Polin, 3 (1988), 78--101.

${ }^{46}$ Mateusz Butrymowicz, Reforma Żydów (1789), in MDSC, vi. 119. The project followed up his pamphlet of February 1789, Sposób uformowania Żydów polskich w pożytecznych krajowi obywatelów, in MDSC, vi. 78--93. See J. Michalski, 'Sejmowe projekty reformy położenia ludności żydowskiej w Polsce w latach 1789--1792', in id., Studia historyczne z XVIII i XIX wieku, ed. W. Kriegseisen and Z. Zielińska, 2 vols. (Warsaw, 2007), i. 305--22; Lukowski, Disorderly Liberty, 214-16; Wodziński, ““Civil Christians”, 50--1.

${ }^{47}$ K. Zienkowska, 'Reforms Relating to the Third Estate', in S. Fiszman (ed.), Constitution and Reform in Eighteenth-Century Poland: The Constitution of 3 May 1791 (Bloomington, Ind., 1997), 344--5. Cf. D. Beales, Joseph II, 2 vols. (Cambridge, 1987--2009), ii. 196--213, 600--3.

${ }^{48}$ K. Zienkowska, 'Obywatele czy mieszkańcy? Nieudana próba reformy statusu Żydów polskich w czasie Sejmu Czteroletniego', in J. Kowecki (ed.), Sejm Czteroletni i jego tradycje (Warsaw, 1991), $158--60$.

${ }^{49}$ Ibid. 158, 165 n. 29. See also K. Zienkowska, Jacek Jezierski, kasztelan tukowski, 1722--1805: Z dziejów szlachty polskiej XVIII wieku (Warsaw, 1963).

${ }^{50}$ Reforma Żydów: Projekt od deputacji do tego wyznaczonej, in MDSC, vi. 217, 228. See Michalski, ‘Sejmowe projekty reformy położenia ludności żydowskiej’, passim.

${ }^{51}$ Michalski, ‘Sejmowe projekty reformy położenia ludności żydowskiej’, 305; Ignacy Chołoniewski, Projekt względem Żydów i dlugów kahalnych żydowskich, in MDSC, vi. 269--71.

${ }^{52}$ Polonsky, Jews in Poland and Russia, i. 216.

${ }^{53}$ In Mazovia: Ciechanów: Biblioteka Polskiej Akademii Umiejętności i Polskiej Akademii Nauk w Krakowie (hereafter BPAU), MS 8318, fos. 369--70; Czersk: BPAU, MS 8320, fo. 497; Różan: BPAU, MS 8337, fos. 635--42; Wyszogród: BPAU, MS 8352, fos. 375--8. In the Grand Duchy of Lithuania: Grodno: Lietuvos mokslų akademijos biblioteka, Vilnius (hereafter LMAB), F233-126, fos. 23--9; Kowno: LMAB, F233-126, fos. 52--5; Orsza: LMAB, F233-126, fos. 124--30; Pińsk: LMAB, F233-126, fos. 138--40; Upita: AGAD, Archiwum Roskie, publica XCV/4/5, fos. 6--8; 
Wilno: LMAB, F233-126, fos. 225--8; Wotkowysk: LMAB, F233-126, fos. 243--5. See also

Lukowski, Disorderly Liberty, 218--19.

${ }^{54}$ On the 1768 Koliyivshchyna, see B. Skinner, 'Borderlands of Faith: Reconsidering the Origins of a Ukrainian Tragedy', Slavic Review, 64/1 (2005), 88--116. For the Volhynian sejmik, see Lukowski,

Disorderly Liberty, 218--19.

${ }^{55}$ Zienkowska, 'Reforms Relating to the Third Estate', 340--1.

${ }^{56}$ Karol Surowiecki, Python: Lipsko-warszawski diabet. Kontr-tragedya na tragedya Saul wyjęta z Pisma Świętego, grana przez aktorów tamtego świata w roku 1789; a w roku 1792 światu ziemskiemu obiawiona (n.p., 1792), 104--5.

${ }^{57}$ A. Zahorski, Centralne instytucje policyjne w Polsce w dobie rozbiorów (Warsaw, 1959), 158-60; J. Gordziejew, Komisje Porządkowe Cywilno-Wojskowe w Wielkim Księstwie Litewskim w okresie Sejmu Czteroletniego (1788--1792) (Kraków, 2010), 127--33. Cf. Polonsky, Jews in Poland and Russia, i. 219--20.

${ }^{58}$ Newsletter, 31 Mar. 1792: Biblioteka Narodowa, Warsaw, Akc. 9830, fos. 39--40.

${ }^{59}$ E. Rostworowski, Maj 1791--maj 1792: Rok monarchii konstytucyjnej (Warsaw, 1985), 15--16;

Stanisław August to Stanisław Małachowski, 2 May 1792, in MDSC, vi. 335.

${ }^{60}$ Hymn . . . dnia 3 maja 1792 . . śspiewany od wszystkich narodu żydowskiego zgromadzeń, in $M D S C$, vi. 480--3. Two quadrilingual editions were published (Hebrew, Polish, French, and German). The Polish version, the basis of my translation, appeared in Gazeta Narodowa i Obca on 19 May 1792. The Hebrew version is printed on plates in $M D S C$, vol. vi, between pp. 480 and 481 . See also K. Maksimowicz, Poezja polityczna a Sejm Czteroletni (Gdańsk, 2000), 238--40. Cf. 'Nature and nature's laws lay hid in night. / God said: "Let Newton be", and all was light': Alexander Pope, 'Epitaph. Intended for Sir Isaac Newton, in Westminster-Abbey', in The Works of Alexander Pope, Esq., 10 vols. (London, 1824), iii. 378.

${ }^{61}$ The chances of passing a reform were assessed as unlikely by Eisenbach, Emancypacja Żydów na ziemiach polskich, 113--22, but as probable by Zienkowska, 'Obywatele czy mieszkańcy?’, 164. Michalski, 'Sejmowe projekty reformy położenia ludności żydowskiej’, 323, established that Eisenbach (on p. 121) had misread a key piece of evidence (a letter from Hugo Kołłątaj to Stanisław 
Małachowski, dated 23 May 1792, in MDSC, vi. 337), confusing a discussion at Małachowski's house with a session of the Sejm. Michalski concluded that the reform might well have been passed, albeit in a modified form, had the Sejm lasted longer. Polonsky's conclusion is decidedly more pessimistic: Jews in Poland and Russia, i. 215--19.

${ }^{62}$ Michalski, ‘Sejmowe projekty reformy położenia ludności żydowskiej’, 306--8, 321, compares the various projects. The final draft of the deputation's final project, Urzadzenie ludu żydowskiego w calym narodzie polskim, is published, alongside indications of changes from the initial draft (dating from January 1792), in $M D S C$, vi. 491--515. According to the editors, this project owed more to the 'Mémoire pour servir de projet à l'établissement des Juifs', in MDSC, vi. 358--72, drawn up by Scipione Piattoli for King Stanisław August in September--October 1791, than it did to the deputation's earlier project, Reforma Żydów.

${ }^{63}$ On the reform of the Orthodox Church in the Commonwealth, see E. Sakowicz, Kościót prawostawny w Polsce w epoce Sejmu Wielkiego, 1788--1792 (Warsaw, 1935), 182--226; K. Paździor, 'Polityka Sejmu Czteroletniego wobec kościołów wschodnich’, Ph.D. diss. (Univ. of Silesia in Katowice, 2000), ch. 4; Butterwick, 'Deconfessionalization?'.

${ }^{64}$ See K. Paździor, 'Edukacja jako narzędzie polityki wyznaniowej Sejmu Wielkiego wobec innowierców', Nasza Przeszłość, 100 (2003), 329--66. Cf. R. J. W. Evans, Austria, Hungary, and the Habsburgs: Essays on Central Europe, c.1683--1867 (Oxford, 2006), 134--69; Beales, Joseph II, ii. 366--70.

\footnotetext{
${ }^{65}$ Hundert, Jews in Poland--Lithuania, 31.
} 